Michelle

$\mathrm{B} / 130218075$

\title{
THE IMPORTANCE OF SUPPORTING MSMEs' DIGITALIZATION IN INDONESIA
}

Due to the Covid-19 pandemic, Indonesia's economy experienced deflation three months in a row from July to September 2020. The Central Bureau of Statistics of the Republic of Indonesia noted a decline in prices for several commodities in the food, beverage, and tobacco category. This deflation occurred mainly because of the lower class's weakening purchasing power and the upper-middle groups' preference to save their money than to spend it. This results in the decrease of micro and small businesses' income by $84 \%$ and medium and large businesses' income by $82 \%$ (Tayibnapis et al., 2021).

Micro, Small, and Medium Enterprises (MSMEs) have a very vital role in the development and economic growth in Indonesia. According to the Ministry of Cooperatives and SMEs, in 2020, MSMEs have a total of $60 \%$ contribution to the Gross Domestic Bruto and $90 \%$ contribution to the national workforce absorption. Therefore, the recovery of MSMEs is very important for the well-being of the national economy. The Covid-19 pandemic must encourage MSMEs actors to transform their businesses if they want to survive. Business digitalization during the Covid-19 pandemic is growing faster. Therefore, the recovery of MSMEs cannot be separated from the utilization of information technology (Tayibnapis et al., 2021).

According to the research results, 36\% of MSMEs in Indonesia are still stuck with conventional marketing. Meanwhile, 37\% of MSMEs only have basic online marketing capacities such as computer access and broadband. The remaining 18\% of MSMEs have medium online capacity because they can use websites and social media. Only $9 \%$ have digital marketing capacity that can be categorized as sophisticated (Erlanitasari et al., 2020). It seems that the process of digitizing MSMEs cannot be done immediately. It is best to join electronic trade organizers, such as Shopee, Tokopedia, Bukalapak, Lazada, and others. Consistent socialization by the government and mentoring by e-commerce companies is necessary to keep up the effort of MSMEs digitalization (Tayibnapis et al., 2021). MSMEs is also a very potential market for the financial services industry, especially banks to channel financing. About 60-70\% of SMES do not yet have access to banking financing due to various factors (Erlanitasari et al., 2020). 
Realizing Indonesia's economic growth is still mainly supported by household consumption expenditures, the government has made an effort to stimulate consumption growth through social protection and assistance to businesses. The growing consumption and purchasing power of the people will prevent Indonesia from an economic recession. In December 2020, the realization of the Economic Recovery Program was recorded at IDR 579.78 trillion or $83.4 \%$ of the ceiling. The highest realization was recorded for MSMEs support, which reached $96.7 \%$ of the reprofiling ceiling. The government's MSMEs protection and rescue schemes, ranging from social assistance, tax incentives, relaxation, and credit restructuring, to expanding financing. Other than that the government has also launched the MSME website and the MSME Digital Market for buying domestic MSME products.

Digital financial services can be the key to drive the internet economy. It is also expected to support the financing of the productive sector. However, despite the large numbers of internet users in Indonesia, the level of literacy of the digital is still low, including among MSMEs. Businesses with digital literacy will better understand the ways of the market, the product, the appropriate target market, and not trick consumers, either intentionally or not. In other words, MSMEs should be encouraged to improve digital literacy and master the marketplace (REFERENCE 2). This can be realized by establishing mature strategies and policies to make the internet an enhancer of the competitiveness of Indonesian MSMEs starting from the supply chain system, production, promotion, and marketing, to payment (Tayibnapis et al., 2021).

One of the efforts that can be done, MSMEs can join the organizers of electronic commerce. Technology-based companies or e-commerce such as Tokopedia, Bukalapak, Kudo, Warung Pintar, and Kiosan seem to continue to synergize with MSMEs entrepreneurs to create sales volume and increase competitiveness in the market. The synergy between business actors is a determinant of success in doing business and build relationship marketing. This mutualistic symbiosis in business partnership can be the solution to resolve many shortcomings, limitations, and problems. Favorable relationships should continue to be developed, not only between MSMEs and large companies but also with fellow MSMEs, cooperatives, private sector, State-owned enterprises, or Regional-owned enterprises (Tayibnapis et al., 2021).

When MSMEs can utilize digital technology, it is potentially accounted for national economic growth by $2 \%$ in the year 2025 . Digital literacy programs must be continued to be 
pursued by the government considering that MSMEs are the driving force of the economy and national development, it is necessary to have a strategy to empower the sector. The MSMEs sector empowerment policy should be directed to support efforts in reducing poverty and inequality, creating employment opportunities, and increasing exports.

\section{REFERENCES}

Erlanitasari, Y., Rahmanto, A., \& Wijaya, M. (2020). Digital economic literacy micro, small and medium enterprises (SMES) go online. Informasi, 49(2), 145-156. https://doi.org/10.21831/informasi.v49i2.27827

Tayibnapis, A. Z., Wuryaningsih, L. E., \& Gora, R. (2021). Medium, Small, and Medium Enterprises and Digital Platforms. South Asian Journal of Social Studies and Economics, 10(2), 10-19. https://doi.org/10.9734/sajsse/2021/v10i230258

Available:https://www.republika.co.id/berita/qj5jvd370/setelah-tiga-bulan-deflasi-indonesiakembali-inflasi

Available:https://www.cnbcindonesia.com/news/20201215131853-4-209208/sedihnya-omzetumkm-turun-30-di-masa-pandemi-covid-19

Available:https://www.tribunnews.com/bisnis/2021/04/28/airlangga-umkm-digital-kuncipemulihan-ekonomi-nasional 